\title{
Histopathologic Changes and the Immune Response within the Jejunal Mucosa in Infants and Children
}

\author{
H. V. L. MAFFEI, D. KINGSTON, ${ }^{(29)}$ I. D. HILL, AND M. SHINER \\ MRC Gastroenterology Unit, Central Middlesex Hospital, London NWI0 7NS; Clinical Research Centre, Watford \\ Road, Harrow, Middlesex, HAI 3UJ, England
}

\begin{abstract}
Summary
Jejunal biopsies obtained from $\mathbf{4 5}$ children referred for a variety of clinical conditions were examined histologically and by standard immunofluorescence methods. The number of plasma cells was recorded per "mucosal tissue unit." The results showed that most of the immunoglobulin A (IgA) counts in infants under $3 \mathrm{yr}$ with normal mucosa were low and that there was a rise in the number of IgA plasma cells starting after this age. Despite this, under pathologic conditions (partial villous atrophy with increased inflammatory cell infiltration - PVA) a significant rise in IgA plasma cells occurred in all age groups. Patients with coeliac disease tended to show the highest IgA as well as IgM plasma cell counts. In all other patients, IgM counts did not change significantly with age or histologic abnormalities.
\end{abstract}

\section{Speculation}

Children in the first few months of life are as capable as older children of increasing the number of IgA plasma cells in their jejunal mucosa. However, though immunocompetent, their gut, on first contact, will be lacking in primary immune responses to the various antigens, and, therefore, may be relatively unprotected.

It is well recognized that, in infants, $\operatorname{IgA}$ in the serum rises slowly and reaches about $70 \%$ of adult serum levels at age $12(27)$. Little is known, however, about the numbers of plasma cells in the gut mucosa in relation to age, although the gut is considered one important site of immunoglobulin production. The only previous studies on this subject were carried out in children in whom no organic intestinal disease was found and in whom the small bowel mucosa was histologically normal $(3,21)$, or grossly abnormal as in coeliac disease (22). Because infants are so often exposed to gastrointestinal infections, it was of interest to study the ability of children to increase their local immunoglobulin production in response to agents causing the pathologic conditions within the small bowel mucosa. We, therefore, set out to study the mucosal immune response by a simple quantitative tissue immunofluorescence technique in patients who were referred to us for a variety of clinical conditions.

\section{MATERIALS AND METHODS}

Forty children included in this study presented consecutively for jejunal biopsy. This was carried out for diagnostic purposes and with the informed consent of the child's parents or guardians. Only bottle-fed children were included. All patients had detailed clinical investigations, examinations of stools and jejunal juice to exclude pathogens. Serum immunoglobulins were determined in most and those with immunodeficiency were excluded. Single jejunal biopsies were carried out as part of the routine diagnostic procedures, but in two of the patients with cow's milk protein intolerance, biopsy was repeated. Older children were less often referred to us for jejunal biopsy, and it was important for this study to extend the analysis of the effect of age. We, therefore, included earlier data, namely, counts from 10 normal adult volunteers and from 5 children aged 2-10 yr with normal jejunal histology. Both sets of results were analysed together.

All the patients are listed in Tables 1,2, and 3.

The Crosby capsule was used for jejunal biopsy, with a pediatric modification of porthole diameters: $2.2 \mathrm{~mm}$ for infants under $1 \mathrm{yr}$ and $2.8 \mathrm{~mm}$ for those over $1 \mathrm{yr}$ of age. The biopsies, obtained at the level of the ligament of Treitz, were divided into at least two portions, one for routine histologic preparation and the other for tissue immunofluorescence. All biopsies were histologically classified into 1) normal mucosa or slight alteration $(N), 2)$ partial villous atrophy defined as short broad villi, increased crypt length and increase in inflammatory cell infiltration (PVA), and 3) subtotal villous atrophy (SVA) (26). For immunofluorescence, the tissue was immediately fixed in $5 \%$ formaldehyde in phosphate buffered saline for $4 \mathrm{hr}$, then washed overnight in $30 \%$ sucrose and stored at $-80^{\circ} \mathrm{C}$. Fluorescein isothiocyanate conjugated antisera against IgA, IgM, IgG, C3 complement and secretory piece were obtained from DAKO and diluted from 1:20 to 1:60. Conjugated IgE antiserum was obtained from Behring and diluted $1: 5$ to $1: 20$. Because of the tendency of the IgG antiserum to stain connective tissue, thus making it difficult to recognize and count IgG plasma cells, a portion of some of the mucosae was separately treated by washing in phosphate buffered saline for $24-48 \mathrm{hr}$ before fixation (6). The frozen tissue was cut on a cryostat at a thickness of $5 \mu \mathrm{m}$, stained on slides with antisera and viewed with a Leitz fluorescence microscope. The plasma cells stained with the monospecific antisera were directly counted at a magnification of $\times 250$ (eyepiece $\times 10$, objective $\times 25$ ) with a $5 \mathrm{~mm} \times 5 \mathrm{~mm}$ grid of 100 subdivisions inserted into the eyepiece. Only vertically orientated sections were counted, using the technique of Brandtzaeg et al. $(4,5)$, in which the total plasma cells contained in a mucosal tissue unit were counted. This unit was defined in our study as a column with a width that of the grid and a height the full height of the mucosa. The width of this column on a slide micrometer was $232 \mu \mathrm{m}$. Whenever possible, 8-15 consecutive units were counted in two different slides stained with the same antisera. Eosinophils and macrophages were excluded from the counts by their different appearance including their ability to scatter red light when a K530 secondary filter was used.

Statistical analysis was performed using Nelder's (17) computer program for generalized linear modelling-GLIM.

\section{RESULTS}

The counts for each biopsy are given in Tables 1,2 , and 3 . Counts for IgA and IgM plasma cells only are shown because no consistent technically satisfactory results were obtained for IgG 
Table 1. Mean plasma cell counts per mucosal unit in patients with normal histology

\begin{tabular}{|c|c|c|c|c|}
\hline \multirow[b]{2}{*}{ Reasons for referral } & \multirow{2}{*}{$\begin{array}{c}\text { Age } \\
\text { (months) }\end{array}$} & \multicolumn{2}{|c|}{ Counts ${ }^{1}$} & \multirow[b]{2}{*}{ Notes } \\
\hline & & $\operatorname{Ig} A$ & IgM & \\
\hline \multirow{11}{*}{$\begin{array}{l}\text { Failure to thrive without diar- } \\
\text { rhea }\end{array}$} & 8 & 25.7 & 7.5 & \\
\hline & 8 & 44.1 & 12.8 & \\
\hline & 9 & 29.9 & 17.2 & \\
\hline & 11 & 50.8 & 3.6 & \\
\hline & 22 & 23.2 & 7.8 & \\
\hline & 27 & 30.2 & 4.1 & \\
\hline & 28 & 34.4 & 7.8 & $\mathrm{a}^{2}$ \\
\hline & 45 & 40.1 & 7.6 & $a^{2}$ \\
\hline & $4 \mathrm{yr}$ & 49.7 & 18.8 & \\
\hline & $61 / 2 \mathrm{yr}$ & 65.0 & 9.0 & \\
\hline & $133 / 4 \mathrm{yr}$ & 38.6 & 15.5 & \\
\hline \multirow{6}{*}{$\begin{array}{l}\text { Diarrhea (more than } 2 \text { weeks } \\
\text { duration) }\end{array}$} & 3 & 24.5 & 53.2 & \\
\hline & 5 & 37.8 & 25.9 & \\
\hline & 24 & 25.4 & 2.7 & \\
\hline & 24 & 37.1 & 7.2 & $a^{2}$ \\
\hline & $4^{1 / 2} \mathrm{yr}$ & 37.4 & 3.3 & $a^{2}$ \\
\hline & $63 / 4 \mathrm{yr}$ & 91.3 & 28.5 & \\
\hline
\end{tabular}

Cow's milk protein intolerance

On cow's milk

Cow's milk eliminated

$\begin{array}{rrr}2 & 54.9 & 5.7 \\ 5 & 36.8 & 2.8 \\ 15 & 29.2 & 10.1 \\ 15 & 32.0 & 19.0 \\ 20 & 39.8 & 12.0\end{array}$

Fibrocystic disease

18

$21.2 \quad 9.2$

Arthritis

$10 \frac{1}{4} \mathrm{yr} \quad 61.0 \quad 10.1$

$\mathrm{a}^{2}$

Normal adults (IgA) counts only: 40.8, 43.8, 49.2, 51.0, 51.3, $53.8,54.4,54.8,60.2,65.8$

' The mean counts are for a mucosal unit with column of width $232 \mu \mathrm{m}$.

${ }^{2}$ These patients comprise the additional selected group (see Materials and Methods).

${ }^{3}$ Same child as b in Table 2.

and IgE. The staining pattern for secretory piece in the epithelial cells was normal throughout, and no significant difference between the biopsies was found for C3.

The first analysis of these results was carried out on the original 40 biopsies grouped according to the patients' age as over and under $2 \mathrm{yr}$, and showing either normal histology (N), partial villous atrophy (PVA) or subtotal villous atrophy (SVA). Multiple regression analysis on the logarithms of the mean counts for the individual biopsies showed a highly significant effect $(P<0.001)$ as between N, PVA, and SVA, but any effect between the two age groups was found to be negligible once other variables had been allowed for. The analysis was rerun using results from all the biopsies. The counts were grouped as N, PVA, and SVA, age being considered on the basis of an assumed linear regression instead of merely as two groups. This analysis showed a highly significant correlation $(P<0.001)$ with histologic classification, and a moderately significant one $(P<0.05)$ with age. Graphical plotting of the data revealed no evidence of any correlation with the disease category. The mean values grouped by age and histologic classification are given in Table 4 and a scatter diagram of the IgA counts in Figure 1.

Regarding age, if the more extensive series of IgA counts with normal histology are examined, it can be seen that the majority of the counts of children under 3 yr old lie below 40 and the majority of those over $3 \mathrm{yr}$ old above. If the median value on each scale is taken for these counts, the number of counts falling into each quarter can be put into the form of a $2 \times 2$ table (Table 5). This table corresponds to an exact probability (28) of $P=0.0004$. There is, therefore, a highly significant increase in the $\operatorname{IgA}$ counts of normal mucosae with age, inspection of the graph suggesting that a change in behavior tends to take place at about the age of 3 . It should be noted that using the median of each scale as a dividing line is an objective procedure, not a subjective trial-and-error method, and that the positions of the medians are independent of whether or not there is any correlation between corresponding values on the two scales. Thus, the ordinary test of significance may safely be used.

Regarding histology, it may be seen (Fig. 1) that there is a nearly complete separation between the $N$ and PVA counts for IgA. A discriminating line drawn at 58 would have only one PVA below, and only $5 \mathrm{~N}$ above (all over age 5 ). The mean values for the children are $40.0(\mathrm{~N})$ and 83.0 (PVA). The SVA counts lie in among the top 5 PVA counts. If the IgM counts in SVA are considered, 4 of the 6 counts lie above 40, a level reached by only $1 \mathrm{~N}$ and I PVA count. In contrast, the IgM counts were not appreciably raised in PVA. It should also be noted that increase in IgA counts with histologic abnormality occurs in all age groups, including the youngest (Table 4).

The ratio IgA:IgM plasma cell counts was examined for the

Table 2. Mean plasma cell counts per mucosal unit in patients with partial villous atrophy

\begin{tabular}{|c|c|c|c|c|}
\hline \multirow[b]{2}{*}{ Reasons for referral } & \multirow{2}{*}{$\begin{array}{c}\text { Age } \\
\text { (months) }\end{array}$} & \multicolumn{2}{|c|}{ Counts } & \multirow[b]{2}{*}{ Notes } \\
\hline & & IgA & IgM & \\
\hline $\begin{array}{l}\text { Failure to thrive without diar- } \\
\text { rhea }\end{array}$ & 6 & 87.0 & 6.0 & $d^{1}$ \\
\hline $\begin{array}{l}\text { Diarrrhea (more than } 2 \text { weeks } \\
\text { duration) }\end{array}$ & $\begin{array}{r}8 \\
11 \\
14 \\
20 \\
24 \\
27\end{array}$ & $\begin{array}{r}61.4 \\
116.2 \\
60.0 \\
62.7 \\
50.0 \\
59.2\end{array}$ & $\begin{array}{r}3.4 \\
48.3 \\
8.0 \\
21.7 \\
8.8 \\
11.0\end{array}$ & \\
\hline Acute diarrhea & 5 & 72.0 & 13.0 & \\
\hline $\begin{array}{l}\text { Cow's milk protein intolerance } \\
\text { On cow's milk }\end{array}$ & $\begin{array}{r}4 \\
5 \\
6 \\
14\end{array}$ & $\begin{array}{r}91.2 \\
72.0 \\
76.3 \\
119.0\end{array}$ & $\begin{array}{r}28.4 \\
9.5 \\
12.3 \\
22.5\end{array}$ & $\begin{array}{l}e^{2} \\
b, c^{3,4} \\
c^{4}\end{array}$ \\
\hline Cow's milk eliminated & 18 & 60.0 & 21.3 & $\mathrm{e}^{2}$ \\
\hline Coeliac disease (untreated) & 5 & 104.3 & 8.0 & \\
\hline Coeliac disease (treated) & $8 \frac{1}{2} \mathrm{yr}$ & 128.0 & 16.0 & \\
\hline Iron deficiency anaemia & $\begin{array}{l}33 / 4 \mathrm{yr} \\
6 \mathrm{yr}\end{array}$ & $\begin{array}{r}69.2 \\
123.0\end{array}$ & $\begin{array}{l}6.4 \\
6.2\end{array}$ & \\
\hline
\end{tabular}

'd. Atopic child.

${ }^{2}$ e. Same child.

${ }^{3} \mathrm{~b}$. Same child as b in Table 1.

4 c. Biopsies taken after challenge with cow's milk.

Table 3. Mean plasma cell counts per mucosal unit in patients with sub-total villous atrophy

\begin{tabular}{ccccc}
\hline & & \multicolumn{2}{c}{ Counts } & \\
\cline { 3 - 4 } Reasons for referral & $\begin{array}{c}\text { Age } \\
\text { (months) }\end{array}$ & IgA & IgM & Notes \\
\hline Coeliac disease & 13 & 105.1 & 43.0 & \\
& 26 & 187.8 & 55.3 & \\
& 45 & 123.6 & 14.8 & \\
& $71 / 2 \mathrm{yr}$ & 116.8 & 40.2 & \\
& $101 / 4 \mathrm{yr}$ & 118.8 & 9.2 & \\
& $15 \mathrm{yr}$ & 140.0 & 60.0 & $\mathrm{f}^{\prime}$ \\
\hline
\end{tabular}

${ }^{1} \mathrm{f}$. Biopsy from this child had too much extracellular immunoglobulin for accurate counts to be possible. 
Table 4. Mean plasma cell count per mucosal unit in different age groups (No. of biopsies in parentheses)

\begin{tabular}{|c|c|c|c|}
\hline \multirow[b]{2}{*}{ Age (months) } & \multicolumn{3}{|c|}{ Histologic classification } \\
\hline & $\mathbf{N}$ & PVA & SVA \\
\hline \multicolumn{4}{|l|}{ IgA } \\
\hline $0-5$ & $38.5(4)$ & 84.9 (4) & $(0)$ \\
\hline $6-11$ & $37.6(4)$ & $85.2(4)$ & (0) \\
\hline $12-23$ & $29.1(5)$ & $75.4(4)$ & $105.1(1)$ \\
\hline $24-35$ & $31.8(4)^{1}$ & $54.6(2)$ & $187.8(1)$ \\
\hline $3-4 \mathrm{yr}$ & $42.4(3)^{1}$ & $69.2(1)$ & $123.6(1)$ \\
\hline $5-15 \mathrm{yr}$ & $64.0(4)^{1}$ & $125.5(2)$ & $125.2(3)^{2}$ \\
\hline All children & $40.0(24)^{1}$ & $83.0(17)$ & $132.0(6)^{2}$ \\
\hline Adults & $52.5 .(10)^{1}$ & & \\
\hline All biopsies & $43.7(34)^{1}$ & & \\
\hline \multicolumn{4}{|l|}{ IgM } \\
\hline $0-5$ & $21.9(4)$ & $14.7(4)$ & $(0)$ \\
\hline $6-11$ & $10.3(4)$ & $17.5(4)$ & (0) \\
\hline $12-23$ & $11.6(5)$ & $18.4(4)$ & $43.0(1)$ \\
\hline $24-35$ & $5.4(4)^{1}$ & $9.9(2)$ & $55.3(1)$ \\
\hline $3-4 \mathrm{yr}$ & $9.9(3)^{1}$ & $6.4(1)$ & $14.8(1)$ \\
\hline $5-15 \mathrm{yr}$ & $15.8(4)^{1}$ & $11.1(2)$ & $36.5(3)^{2}$ \\
\hline All children & $12.6(24)^{1}$ & $14.8(17)$ & $37.1(6)^{2}$ \\
\hline Adults & $14.6(4)^{1}$ & & \\
\hline
\end{tabular}

'These figures include the additional selected biopsies (see Materials and Methods); the adults are entirely from this group. If the additional biopsies are excluded from the counts for children the values become, respectively: IgA—27.8 (2), 49.6 (1), 65.0 (3), all children, 39.5 (19); IgM$3.4(2), 18.7$ (1), 17.7 (3), all children, 14.0 (19).

${ }^{2}$ These figures include estimated counts of $140(\operatorname{IgA})$ and $60(\operatorname{IgM})$ for a biopsy taken from a 15 -yr-old girl in which the amount of extracellular immunoglobulin made any exact count impossible.

$\mathbf{N}=$ normal; PVA = partial villous atrophy; $\mathbf{S V A}=$ subtotal villous atrophy. This mucosal unit is based on a column width of $232 \mu \mathrm{m}$. The mean counts in this table should therefore be multiplied by 2.15 to bring the unit up to the size of Brandtzaeg's (4).

original 40 patients grouped as over and under 2 . It was lowest for those patients under age 2 with normal mucosae. The correlation between IgA and IgM counts in normal mucosae showed a nonsignificant inverse relationship under the age of 2 , but a significant $(P<0.01)$ direct relationship over 2 . The under 2 inverse correlation became virtually zero if one discrepant observation (IgM $=53.2$ ) was omitted. However, it should be noted that two of the three highest values for IgM associated with normal histology occurred in children under 6 months old.

\section{DISCUSSION}

In this study, a method of counting was used similar to that of Brandtzaeg and associates $(2,4,5)$. This gives a measure of the number of plasma cells per unit length of gut. We consider it to be superior in principle to techniques involving measuring the number of cells per unit area, because the latter takes no account of the great increase in SVA of the area which contains high densities of plasma cells. However, it does mean that numerical values cannot be directly compared with those obtained by some other workers. If our figures are multiplied by 2.15 to bring our mucosal unit up to the size of Brandtzaeg's $(500 \mu \mathrm{m})$ comparable values are found. Thus, Baklien et al. (2) give mean counts for normal adults of 103 (IgA) and $24(\operatorname{IgM})$; our values are 113 and 31. For adult coeliacs, their figures were 228 (IgA) and 63 (IgM), which may be compared with ours for child coeliacs of 284 and 80 . Their four (elderly) adult PVAs had mean counts of 238 and 40, compared with our means for children with PVA of 178 and 32.

It is possible that there may be some correlation of plasma cell count with specific diagnosis, but this is not apparent from our limited data. Thus, for the patients we have so far examined, plasma cell counts did not seem to have diagnostic value. The best correlation occurred with coeliac disease, but though the IgA counts were high in all cases, comparable levels were sometimes found in other diseases with PVA. High IgM counts $(>40)$ were present in $4 / 6$ coeliac patients with SVA, but not in 2 other coeliacs with PVA (Tables 2). These levels were also found in two other (noncoeliac) patients. Other workers $(15,16,19,24)$ have also drawn attention to increased concentration of IgM plasma cells as part of coeliac disease, but we have found this increase inconsistent. Savilahti (22) found increased IgM counts when patients with cows' milk protein intolerance were challenged, but high IgM counts are not associated with cows' milk protein intolerance in our patients.

We set out to examine both the effect of age on the number of plasma cells in normal jejunal mucosae, and also whether age affected the ability of the gut to respond immunologically to abnormal stimuli. This study is necessarily limited for ethical reasons because the children, even those with histologically normal mucosae, were referred for suspected jejunal abnormality. Also, the patients tended to be referred for different clinical conditions at different ages, though as we could not find a correlation with the diagnosis (only with histologic abnormality), we do not consider this a serious limitation.

The literature is scarce on the plasma cell counts in the intestinal mucosa related to age. Savilahti (23) reported children with histologically normal mucosae biopsied for actual or suspected intes-

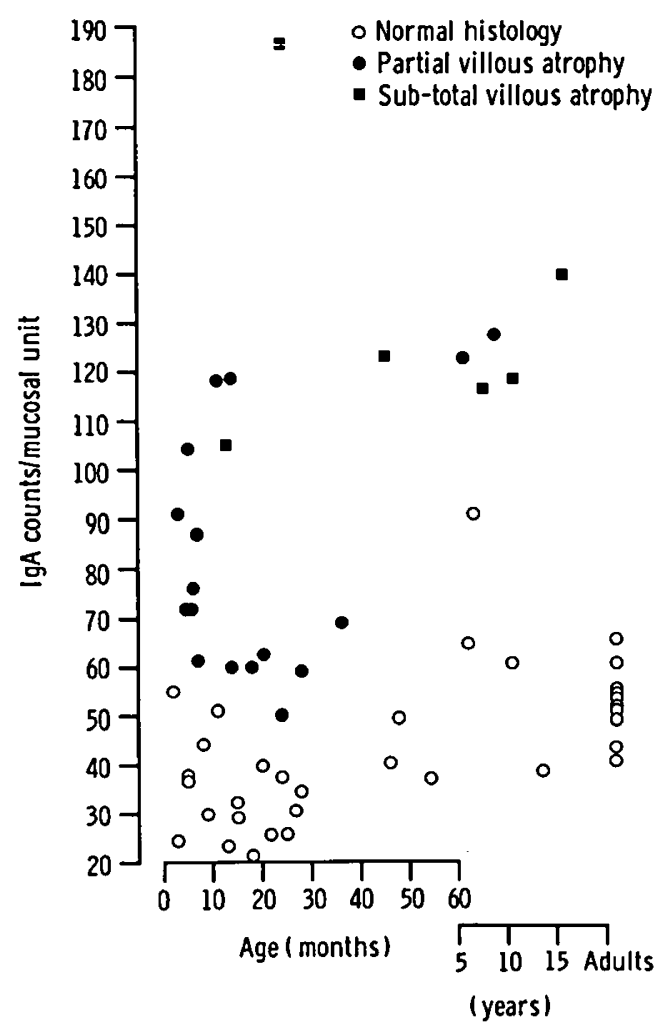

Fig. 1. IgA plasma cell counts with age.

Table 5. IgA counts, normal histology, divided into four groups by median age and median count. No. in each quarter. ${ }^{1}$

\begin{tabular}{lccc}
\hline & \multicolumn{2}{c}{ Age (yr) } & \\
\cline { 2 - 3 } \multicolumn{1}{c}{ Count } & Under 3 & Over 3 & Total \\
\hline Under 40.05 & 14 & 3 & 17 \\
Over 40.05 & 3 & 14 & 17 \\
Total & 17 & 17 & 34 \\
\hline
\end{tabular}

\footnotetext{
${ }^{1} P=0.0004$.
} 
tinal malfunction. He found an increased concentration of $\operatorname{IgA}$ plasma cells in the over 2-year-old group as compared with the under 2-year-olds, but with a great deal of overlap. Multiple regression analysis (see Results) showed that this division into under and over 2 did not give a significant result for our original data. If all our biopsies with normal histology are considered (Tables 1, 4, and 5, Fig. 1), it is clear that there is an increase with age, though this is not shown clearly by the mean values (Table 4). Reference to Figure 1 suggests that these means are overweighted by occasional high values. The comparatively small effect of age on the plasma cell counts which we found is supported by a study of fecal immunoglobulin levels in normal children (9).

It would be unwise to believe that plasma cell counts, especially IgA counts, would be comparable in breast-fed and bottle-fed infants. All the children in our series were bottle-fed. There is evidence that cows' milk protein intolerance can lead to an increase in the IgA plasma cell concentration in jejunal biopsies, usually associated with PVA $(8,10,11,12,24,25)$ : There is also evidence that feeding mice whole cows' milk, compared with hydrolyzed milk protein, can give rise to increased IgA plasma cell concentration without obvious signs of villous atrophy (20). In pigs, the rise in the concentration of IgA plasma cells coincides with weaning (1), suggesting that the presence of foreign food antigens may be responsible. In the only breast-fed patient, aged $4 \frac{1}{2}$ months, that we biopsied (not included in this study), the histology showed a PVA of the jejunal mucosa, and the IgA plasma cell counts (42.8) were below the PVA range of our bottlefed patients, though IgM (12.3) was within the usual range. This occasional observation supports the cited findings in animals.

Like us, Savilahti (23) found no change in IgM plasma cell counts with age. Because he reported an increase in IgA plasma cell counts with age, the IgA:IgM ratio rose and this he ascribed to the immaturity of the IgA system in young children. Results supporting this have been found in pigs $(1,7)$. Blanco et al. (3), studying 24 normal children, found no significant increase in IgA plasma cells after age 1, but a significant decrease in IgM cells after that age. An inverse correlation between $\operatorname{IgA}$ and $\mathrm{IgM}$ counts would suggest a compensatory mechanism in early ages similar to that observed in IgA deficiency (21). However, in our series, when IgA and IgM counts for individual biopsies were compared, there was no significant evidence of this inverse relationship. Although the lowest ratios occurred in children under 20 months, three of the highest ratios also occurred in that group.

The highly significant increase in $\operatorname{IgA}$ plasma cells in PVA and SVA occurs as much in the youngest children in our series as the oldest (Fig. 1 and Table 4). Savilahti (24) found that children under 2 with coeliac disease had IgA and IgM counts in the same range as children over 2 . This is also true of our patients. The correlation of increased plasma cell counts (especially $\operatorname{IgA}$ ) with mucosal damage could be explained by an increased permeability to antigen in the damaged mucosa. It has been found that there is a correlation between degree of histologic abnormality and the occurrence of antibodies to food in coeliac disease and dermatitis herpetiformis (13). It is also possible that the immune response might be responsible for the damage, though there are doubts whether IgA can be regarded as complement-fixing (14).

The general opinion that there is an increased incidence of gastrointestinal disturbance in young children is borne out by the age distribution of the children coming to us for biopsy. Though even the youngest of the children studied here seemed to be capable of mounting a full $\operatorname{IgA}$ response in PVA, the number of plasma cells in normal mucosae was in most of them well below that of adults. There is dispute as to whether the intestinal mucosa demonstrates immunological memory, though recent work on immunity to cholera (18) suggests that it does. Thus, a simple explanation of our findings would be that the infants' mucosa, though immunologically competent, had encountered relatively few pathogens and other damaging agents, and was, therefore, comparatively unprimed and unprotected. This may well explain the increased incidence of severe gastroenteritis and persistent diarrhea in smaller infants without breast milk protection.

\section{REFERENCES AND NOTES}

1. Allen, W. D., and Porter, P.: The relative frequencies and distribution of immunoglobulin-bearing cells in the intestinal mucosa of neonatal and weaned pigs and their significance in the development of secretory immunity. Immunology, 32: 819 (1977).

2. Baklien, K., Brandtzaeg, P., and Fausa, O.: Immunoglobulins in jejunal mucosa and serum from patients with adult coeliac disease. Scand. J. Gastroenterol., 12: 149 (1977).

3. Blanco, A., Linares, P., Andión, R., Alonso, M., and Sánchez Villares, E.: Development of humoral immunity system of the small bowel. Allergol. et Immunopathol., 4: 235 (1976).

4. Brandtzaeg, P., and Baklien, K.: Immunohistochemical studies of the formation and epithelial transport of immunoglobulins in normal and diseased human intestinal mucosa. Scand. J. Gastroenterol., 11: (suppl.) 36 (1976).

5. Brandtzaeg, P., Baklien, K., Fausa, O., and Hoel, P. S.: Immunohistochemical characterisation of local immunoglobulin formation in ulcerative colitis. Gastroenterology, 66: 1123 (1974).

6. Brandtzaeg, P., and Kraus, F. W.: Autoimmunity and periodontal disease. Odontologisk Tidskrift, 73: 281 (1965).

7. Brown, P. J., and Bourne, F. J.: Development of immunoglobulin-containing cel! populations in intestine, spleen, and mesenteric lymph node of the young pig, as demonstrated by perioxidase-conjugated antiserums. Amer. J. Vet. Res., 37: 1309 (1976).

8. Fontaine, J. L., and Navarro, J.: Small intestinal biopsy in cow's milk protein allergy in infancy. Arch. Dis. Childhood, 50: 357 (1975).

9. Haneberg, B., and Aarskog, D.: Human faecal immunoglobulins in healthy infants and children, and in some with diseases infecting the intestinal tract or the immune system. Clin. Exptl. Immunol, 22: 210 (1975).

10. Harrison, M., Kilby, A., Walker-Smith, J. A., France, N. E., and Wood, C. B. S.: Cow's milk protein intolerance: a possible association with gastroenteritis, lactose intolerance, and IgA deficiency. Brit. Med. J., 1: 1501 (1976).

11. Jos, J., Rey, J., and Frézal, J.: Etude immuno-histochimique de la muqueuse intestinale chez l'enfant. I. Les syndromes de malabsorption. Arch. Franç. Péd., 29: 681 (1972).

12. Kuitunen, P., Visakorpi, J. K., Savilahti, E., and Pelkonen, P.: Malabsorption syndrome with cow's milk intolerance. Arch. Dis. Childhood, 50: 351 (1975).

13. Kumar, P. J., Ferguson, A., Lancaster-Smith, M., and Clark, M. L.: Food antibodies in patients with dermatitis herpetiformis and adult coeliac diseaserelationship to jejunal morphology. Scand. J. Gastroenterol., I1: 5 (1976).

14. Lamm, M. E.: Cellular aspects of immunoglobulin A. Advanc. Immunol., 22: 223 (1976).

15. Lancaster-Smith, M., Joyce, S., and Kumar, P.: Immunoglobulins in the jejunal mucosa in adult coeliac disease and dermatitis herpetiformis after the reintroduction of dietary gluten. Gut, 18: 887 (1977).

16. Lancaster-Smith, M., Packer, S., Kumar, P. J., and Harries, J. T.: Immunological phenomena in the jejunum and serum after reintroduction of dietary gluten in children with treated coeliac disease. J. Clin. Pathol., 29: 592 (1976).

17. Nelder, J. A.: GLIM (Generalized Linear Interactive Modelling Program). Appl. Statist., 24: 259 (1975).

18. Pierce, N. F., and Sack, R. B.: Immune response of the intestinal mucosa to cholera toxoid. J. Infect. Dis., 136: (suppl.) S113 (1977).

19. Ratnaike, R. N., Wilson, J., and Wangel, A. G.: Immunological abnormalities in coeliac disease and their response to dietary restriction. II. Immunoglobulin containing cells, immunoglobulins and dietary antibodies in the small bowel. Aust. N. Z. J. Med., 7: 353 (1977).

20. Sagie, E., Tarabulus, J., Maeir, D. M., and Freier, S.: Diet and development of intestinal IgA in the mouse. Israel J. Med. Sci., 10: 532 (1974).

21. Savilahti, E.: IgA deficiency in children. Immunoglobulin-containing cells in the intestinal mucosa, immunoglobulins in secretions and serum $\lg A$ levels. Clin. Exptl. Immunol., 13: 395 (1973).

22. Savilahti, E.: Immunochemical study of the malabsorption syndrome with cow's milk intolerance. Gut, 14: 491 (1973).

23. Savilahti, E.: Immunoglobulin-containing cells in the intestinal mucosa and immunoglobulins in the intestinal juice in children. Clin. Exptl. Immunol., 11: 415 (1972).

24. Savilahti, E.: Intestinal immunoglobulins in children with coeliac disease. Gut, 13: 958 (1972).

25. Shiner, M., Ballard, J., Brook, C. G. D., and Herman, S.: Intestinal biopsy in the diagnosis of cow's milk protein intolerance without acute symptoms. Lancet, 2: 1060 (1975).

26. Shiner, M., and Doniach, I.: Histopathologic studies in steatorrhoea. Gastroenterology, 38: 419 (1960).

27. Stiehm, E. R., and Fudenberg, H. H.: Serum levels of immune globulins in health and disease. Pediatrics, 37: 715 (1966).

28. Swinscow, T. D. V.: Statistics at Square One, 2nd ed., chapt. 9 Exact Probability Test, p. 54 (British Medical Association, London, 1977).

29. Requests for reprints should be addressed to: Mr. D. Kingston, Division of Clinical Investigation, Clinical Research Centre, Harrow, Middx., HAl 3UJ, UK.

30. Received for publication August 2, 1977.

31. Accepted for publication June 15, 1978. 